\title{
BIMBINGAN TEKNIS PENATAAN ADMINISTRASI KANTOR GUNA MUNUNJANG TERTIB ADMINISTRASI DI KANTOR LURAH ANDOWIA, KECAMATAN ANDOWIA, KABUPATEN KONAWE UTARA
}

${ }^{1}$ Sartono, Muh. Zein Abdullah ${ }^{2}$, Muh. Yusuf ${ }^{3}$, Adrian Tawai ${ }^{4}$, La Ode Aslim ${ }^{5}$

${ }^{12345}$ Fakultas IImu Sosial dan IImu Politik Universitas Halu Oleo

Jl. HEA Mokodompit No.1 Kampus Bumi Tridharma Anduonohu, Kendari 93232

\section{RINGKASAN}

Informasi menjadi bagian yang penting untuk mendukung proses kerja administrasi dan pelaksaan fungsi-fungsi manajemen dari organisasi pelayanan di dalam menghadapi perubahan situasi dan kondisi yang berkembang dengan cepat. Fokus kajian ini adalah penataan administrasi perkantoran yakni kearsipan, ketatausahaan, dan tata hubung kantor dalam rangka guna menunjang tertib administrasi. Berbagai kendala pengelolaan arsip di kantor Kecamatan Andowia, seperti kurangnya pengetahuan arsiparis maupun terbatasnya sarana dan prasarana. Kendala tersebut ditandai dengan kurangnya perhatian khusus terhadap ruangan untuk penyimpanan arsip, lemari arsip yang kurang memadai didukung dengan banyaknya arsip yang disimpan setiap bagian bidang pekerjaan dan kurangnya perawatan khusus juga menjadi alasan kurang tepatnya pengelolaan arsip dan kurangnya keterampilan dan komitmen dalam penataan administrasi kantor di kantor Kecamatan Andowia. Pemerintah yang ada di Kelurahan Andowia Kecamatan Andowia Kabupaten Konawe Utara belum mampu mengatur atau menata administrasi Kelurahan Andowia dengan baik, sebab pemerintah Kelurahan Andowia belum memahami butul pentingnya administrasi Kelurahan Andowia dalam penataan pemerintahan. Sehingga, proses pelaksanaan administrasi menjadi lambat dan tidak sesuai dengan tujuan yang ingin dicapai.

Pemerintah Kelurahan Andowia belum efektif dalam proses pelaksanaan administrasi Kelurahan Andowia, karna masih banyak Pelaksanaan administrasi yang belum dapat diselesaikan, seperti jenis administrasi umum dokumen kepemilikan tanah Kelurahan Andowia Kecamatan Andowia yang kami amati saat ini tidak ada catatan apa pun dalam dokumen tersebut. Ini yang menyebabkan keberhasilan Pemerintah Kelurahan Andowia dinilai masih kurang baik dalam penataan pemerintahan.

Kata kunci: bimbingan teknis; tertib administrasi; perkantoran; Kel. Andowia

\section{A. Latar Belakang \\ 1. (Analisis Situasi)}

Manajemen kantor adalah seluruh pelaksanaan penataan yang berhubungan dengan pelaksanaan tata usaha sebuah organisasi pelayanan supaya proses tersebut mampu menyediakan informasi yang bermakna bagi proses pembuatan keputusan. Tujuan administrasi perkantoran secara umum yakni menerapkan dan mengembangkan kemampuan berkomunikasi baik lisan maupun tertulis dengan relasi memperhatikan norma dan lingkungan masyarakat, menerapkan dan mengembangkan kemampuan untuk merencarakan, melaksanakan, 
mengorganisasi pelayanan dan mengefaluasi tugas yang menjadi tanggung jawab, menerapkan mengembangkan pelayanan terhadapa relasi sehingga diperoleh manfaat masuing-masing pihak menerapkan, dan mengembangkan kemampuan mengelola administrasi keuangan sehingga aspek keuangan dapat dilaporkan dan dipertanggungjawabkan

Ruang lingkup kajian administrasi perkantoran meliputi ruang perkantoran, komunikasi, Aparat kantor, perabot dan perlengkapan kantor, peralatan dan mesin kantor, perbekalan dan keperluan tulis, metode kerja, warkat, pengawasan pejabat pelaksana (Hendi: 2000)

Menata ruang kantor merupakan kebutuhan dari perkantoran moderen saat ini penataan ruang kantor memberi nilai tambah bagi kelangsungan aktifitas perusahaan. Tata ruang kantor merupakan pengaturan dan penyusunan seluruh mesin kantor alat perlengkapan kantor, serta perabot kantor pada tempat yang tepat, sehingga Aparatdapat bekerja dengan baik, nyaman, leluasa dan bebas untuk bergerak, sehingga tercapai efisiensi kerja (Sedarmayanti, 2001 :125).

Administrasi memiliki unsur seperti sekelompok orang, kerjasama, pembagian tugas secara struktur, Pelaksanaan yang rutin dalam proses tujuan yang akan dicapai dan pemanfaatan berbagai sumber, setiap Pelaksanaan administrasi senantiasa diawali dengan sebuah perencanaan tentang tujuan yang hendak dicapai, bagaimana mengawasinya, administrasi bermanfaat sebagai penunjang pekerjaan yang bersifat teknis dan merupakan kunci keberhasilan setiap Pelaksanaan organisasi pelayanan oleh karena itu pengelolaan suatu Pelaksanaan sebaiknya dilaksanakan dengan tertib administrasi, menurut Ismail Saleh 1988 mengemukakan ada beberapa indikator tertib administrasi antar lain terciptanya kelencaran kerja, tersedianya data yang otentik, tersedianya pemdokumenan keuangan yang rapi dan tepat sehingga pengelewengan tidak terjadi, penyimpanan arsip dan terciptanya sistem kerja yang efektif dan efisien.

Fokus pada penataan administrasi kantor pertama, Menurut Wursanto, (2007:95) tata ruang perkantoran adalah suatu penyusunan perabotan dan perlengkapan pada luas lantai yang tersedia dikantor untuk menyiapkan suatu susunan praktis faktorfaktor fisik yang dianggap perlu bagi pelaksanaan pekerjaan perkantoran dengan biaya yang layak senada dikatakan Laksmi dkk, (2008:163). Tujuan tata ruang kantor adalah untuk mencegah penghamburan tenaga dan waktu para pegawai, memahami kelancaran atau kemudahan bagi arus kerja atau komunikasi, kemungkinan pemakaian ruang kerja secara efisien, memudahkan pengawasan, memberikan kondisi kerja yang baik bagi setiap orang, dan memberikan prifasi dan keamanan pada dasarnya dikenal 4 macam tata ruang kantor yakni, tata ruang kantor pertama, tata ruang kantor terbuka, tata ruang kantor berias, dan tata ruang kantor yang merupakan gabungan dalam mewujudkan tata ruang kantor yang sesuai dengan tuntutan kebutuhan kerja yang diperlukan perencanaan tata ruang kantor secara tepat dimana meliputi penyususnan perabot kantor, perlengkapan dan mesin kantor serta arus pekerjaan untuk menciptakan jumlah pergian minimum sehingga tercapai asas tata ruang kantor yang meliputi asas jarak pendek, asas rangkaian kerja, asas penggunanaan ruangan, dan asas perubahan, sebuah tata ruang kantor tidak dapat dipisahkan dengan kondisi lingkungan fisik di sekitarnya, karena kondisi fisik kantor cukup mempengaruhi kondisi karyawan dimana akan 
mengakibatkan kebiasaan yang baik. Menurut Moekijat (2002: 135-136), diantara faktor-faktor penting dari kondisi-kondisi kerja fisik dalam kebanyakan kantor adalah, penerangan, warna, musik, udara, dan suara.

Kedua, menyimpan berbagai sumber informasi penting bagi setiap pelaksanaan atau aktifitas kantor sehari-hari. Informasi tersebut dapat berupa catatan atau rekaman baik berupa suara maupun video dari setiap pelaksanaan yang dilakukan sebagai alat bantu untuk mengingat. Oleh karena itu, arsip harus disimpan dengan baik, rapi dan benar supaya sewaktu-waktu diperlukan dapat ditemukan dengan cepat dan tepat, sehingga pelaksanaan kearsipan dapat berjalan dengan lancar. Amsyah (2005:178) menyebutkan bahwa "untuk dapat menata arsip dengan kecepatan tinggi dan sedikit kesalahan diperlukan peralatan dan pelengkapan yang sanggup menjalankan fungsi setiap sistem dan metode dengan sebaik-baiknya."

Sebagai rekaman informasi dari seluruh aktifitas instansi, arsip berfungsi sebagai pusat ingatan sebagai alat bantu pengambilan keputusan, bukti eksitensi organisasi pelayanan dan untuk kepentingan organisasi pelayanan lain. Berdasarkan fungsi arsip yang sangat penting tersebut, maka harus ada manajemen atau pengelolaan arsip yang baik sejak penciptaan kami dengan penyusutan. Pengelolaan tersebut dilakukan oleh setiap instansi.

Setiap pelaksanaan administrasi instansi pemerintah maupun swata, tidak pernah lepas dari pelaksanaan kearsipan. Keseluruhan pelaksanaan tersebut pada dasarnya membutuhkan informasi. Informasi menjadi bagian yang penting untuk mendukung proses kerja administrasi dan pelaksaan fungsi-fungsi manajemen dari organisasi pelayanan di dalam menghadapi perubahan situasi dan kondisi yang berkembang dengan cepat. Arsip bukan hanya berupa tumpukan kertas semata tetapi lebih dari itu, arsip memiliki arti dan peranan yang besar dalam instansi. Sebuah arsip tidaklah terdiri dari kertas saja, akan tetapi yang lebih penting adalah bagaimana kertas itu dapatdigunakan unutk memberikan informasi, setiap kegiatan atau peritiwa yang terjadi dapat direkan pada arsip.

Menurut Mulyono dkk, (2010:7) "ada arsip yang perlu disimpan sementara (kami 1 tahun, sebagian lagi disimpan 1-5 tahun, yang lain 5-10 tahun, dan sebagian kecil dari jumlah arsip perlu di simpan secara abadi)". Terkait dengan penemuan kembali, Mulyono dkk. (2010:52) menyatakan "untuk mengukur cepat tidaknya penemuan arsip yang diperlukan ditentukan jangka 3 kami 6 menit untuk arsip dinamis dan 6-10 menit untuk arsip statis".

Instansi pemerintahan yang menghasilkan arsip setiap harinya, salah satunya adalah instansi tingkat kecamatan. Setiap hari efektif kerja di kantor kecamatan Andowia tidak lepas dari penciptaan atau penambahan arsip. Arsip yang semakin hari semakin bertambah dan menumpuk setiap hari membutuhkan pengelolaan arsip yang baik. Arsip di kantor Kecamatan Andowia sendiri memiliki beberapa golongan arsip. Arsip yang perlu disimpan dalam jangka waktu tertentu, misalnya data pembuatan KTP dan Kartu Keluarga (KK) warga Kecamatan Andowia dan ada beberapa jenis arsip yang harus disimpan secara abadi. Contoh surat perjanjian dan beberapa piagam penghargaan. Secara administratif, Kecamatan Andowia terdiri dari 6 Kelurahan, yakni Kelurahan Andowia, Tobimeita, Fetoaha, Bungkutoko, Sambuli, dan Tononggeu. Dalam fokus kajian ini adalah penataan administrasi 
perkantoran yakni kearsipan, ketatausaha, dan tata hubung kantor dalam rangka guna menunjang tertib administrasi.

Berbagai kendala pengelolaan arsip dikantor Kecamatan Andowia, seperti
rangnya pengetahuan arsiparis maupun terbatasnya sarana dan prasarana,
tara lain kurangnya perhatian khusus terhadap ruangan untuk penyimpanan
sip, lemari arsip yang kurang memadahi didukung dengan banyaknya arsip yang
impan setiap bagian bidang pekerjaan dan kurangnya perawatan khusus juga
enjadi alasan kurang tepatnya pengelolaan arsip dan kurangnya keterampilan dan
mitmen dalam penataan administrasi kantor di kantor Kecamatan Andowia.
rdasarkan uraian diatas dapat didefinisikan permasalahan sebagai berikut;
nimnya pemahaman Aparatur Sipil Negara dan masyarakat, tentang penataan
ministrasi kantor dalam hal ini perencanaan kantor, pengorganisasi pelayananan
tor, pelaksanaan kantor dan pengawasan kantor, minimnya keterampilan
mitmen dan kepedulian Aparatur Sipil Negara untuk menjalankan tugas
etode Pelaksanaan
Persiapan dan Rekrutmen Peserta
Persiapan yang dilakukan untuk Pelaksanaan pengabdian kepada masyarakat
adalah sebagai berikut:
a) Melakukan koordinasi dengan Kecamatantarget pekerjaan pengabdian pada
masyarakat.
b) Mengidentifikasi kebutuhan bimbingan teknis yang sangat menKelurahan
Andowiak dan dibutuhkan oleh pemerintah Kecamatan, Kelurahan Andowia
dan lembaga pemberdayaan masyarakat lainnya.
c) Mengidentifikasi peserta bimbingan teknis.
d) Memprsiapkan logistik dan perbekalan.

Berbagai kendala pengelolaan arsip dikantor Kecamatan Andowia, seperti
kurangnya pengetahuan arsiparis maupun terbatasnya sarana dan prasarana,
antara lain kurangnya perhatian khusus terhadap ruangan untuk penyimpanan
arsip, lemari arsip yang kurang memadahi didukung dengan banyaknya arsip yang
disimpan setiap bagian bidang pekerjaan dan kurangnya perawatan khusus juga
menjadi alasan kurang tepatnya pengelolaan arsip dan kurangnya keterampilan dan
komitmen dalam penataan administrasi kantor di kantor Kecamatan Andowia.
Berdasarkan uraian diatas dapat didefinisikan permasalahan sebagai berikut;
minimnya pemahaman Aparatur Sipil Negara dan masyarakat, tentang penataan
Administrasi kantor dalam hal ini perencanaan kantor, pengorganisasi pelayananan
kantor, pelaksanaan kantor dan pengawasan kantor, minimnya keterampilan
Aparatur Sipil Negara dalam pelaksanaan tertib Administrasi, Belum terwujudnya
komitmen dan kepedulian Aparatur Sipil Negara untuk menjalankan tugas
Metode Pelaksanaan
1. Persiapan dan Rekrutmen Peserta
Persiapan yang dilakukan untuk Pelaksanaan pengabdian kepada masyarakat
adalah sebagai berikut:
a) Melakukan koordinasi dengan Kecamatantarget pekerjaan pengabdian pada
masyarakat.
b) Mengidentifikasi kebutuhan bimbingan teknis yang sangat menKelurahan
Andowiak dan dibutuhkan oleh pemerintah Kecamatan, Kelurahan Andowia
c) Mengidentifikasi peserta bimbingan teknis.
d) Memprsiapkan logistik dan perbekalan.
M) KoOanna.

Berbagai kendala pengelolaan arsip dikantor Kecamatan Andowia, seperti
kurangnya pengetahuan arsiparis maupun terbatasnya sarana dan prasarana,
antara lain kurangnya perhatian khusus terhadap ruangan untuk penyimpanan
arsip, lemari arsip yang kurang memadahi didukung dengan banyaknya arsip yang
disimpan setiap bagian bidang pekerjaan dan kurangnya perawatan khusus juga
menjadi alasan kurang tepatnya pengelolaan arsip dan kurangnya keterampilan dan
komitmen dalam penataan administrasi kantor di kantor Kecamatan Andowia.
Berdasarkan uraian diatas dapat didefinisikan permasalahan sebagai berikut;
minimnya pemahaman Aparatur Sipil Negara dan masyarakat, tentang penataan
Administrasi kantor dalam hal ini perencanaan kantor, pengorganisasi pelayananan
kantor, pelaksanaan kantor dan pengawasan kantor, minimnya keterampilan
Aparatur Sipil Negara dalam pelaksanaan tertib Administrasi, Belum terwujudnya
komitmen dan kepedulian Aparatur Sipil Negara untuk menjalankan tugas
Metode Pelaksanaan
1. Persiapan dan Rekrutmen Peserta
Persiapan yang dilakukan untuk Pelaksanaan pengabdian kepada masyarakat
adalah sebagai berikut:
a) Melakukan koordinasi dengan Kecamatantarget pekerjaan pengabdian pada
masyarakat.
b) Mengidentifikasi kebutuhan bimbingan teknis yang sangat menKelurahan
Andowiak dan dibutuhkan oleh pemerintah Kecamatan, Kelurahan Andowia
dan lembaga pemberdayaan masyarakat lainnya.
d) Memprangiapkan logistik dan perbekalan.
M) Konts.

Berbagai kendala pengelolaan arsip dikantor Kecamatan Andowia, seperti
kurangnya pengetahuan arsiparis maupun terbatasnya sarana dan prasarana,
antara lain kurangnya perhatian khusus terhadap ruangan untuk penyimpanan
arsip, lemari arsip yang kurang memadahi didukung dengan banyaknya arsip yang
disimpan setiap bagian bidang pekerjaan dan kurangnya perawatan khusus juga
menjadi alasan kurang tepatnya pengelolaan arsip dan kurangnya keterampilan dan
komitmen dalam penataan administrasi kantor di kantor Kecamatan Andowia.
Berdasarkan uraian diatas dapat didefinisikan permasalahan sebagai berikut;
minimnya pemahaman Aparatur Sipil Negara dan masyarakat, tentang penataan
Administrasi kantor dalam hal ini perencanaan kantor, pengorganisasi pelayananan
kantor, pelaksanaan kantor dan pengawasan kantor, minimnya keterampilan
Aparatur Sipil Negara dalam pelaksanaan tertib Administrasi, Belum terwujudnya
komitmen dan kepedulian Aparatur Sipil Negara untuk menjalankan tugas
Metode Pelaksanaan
1. Persiapan dan Rekrutmen Peserta
Persiapan yang dilakukan untuk Pelaksanaan pengabdian kepada masyarakat
adalah sebagai berikut:
a) Melakukan koordinasi dengan Kecamatantarget pekerjaan pengabdian pada
masyarakat.
b) Mengidentifikasi kebutuhan bimbingan teknis yang sangat menKelurahan
Andowiak dan dibutuhkan oleh pemerintah Kecamatan, Kelurahan Andowia
dan lembaga pemberdayaan masyarakat lainnya.
d) Memprangiapkan logistik dan perbekalan.
M) Konts.

Berbagai kendala pengelolaan arsip dikantor Kecamatan Andowia, seperti
kurangnya pengetahuan arsiparis maupun terbatasnya sarana dan prasarana,
antara lain kurangnya perhatian khusus terhadap ruangan untuk penyimpanan
arsip, lemari arsip yang kurang memadahi didukung dengan banyaknya arsip yang
disimpan setiap bagian bidang pekerjaan dan kurangnya perawatan khusus juga
menjadi alasan kurang tepatnya pengelolaan arsip dan kurangnya keterampilan dan
komitmen dalam penataan administrasi kantor di kantor Kecamatan Andowia.
Berdasarkan uraian diatas dapat didefinisikan permasalahan sebagai berikut;
minimnya pemahaman Aparatur Sipil Negara dan masyarakat, tentang penataan
Administrasi kantor dalam hal ini perencanaan kantor, pengorganisasi pelayananan
kantor, pelaksanaan kantor dan pengawasan kantor, minimnya keterampilan
Aparatur Sipil Negara dalam pelaksanaan tertib Administrasi, Belum terwujudnya
komitmen dan kepedulian Aparatur Sipil Negara untuk menjalankan tugas
Metode Pelaksanaan
1. Persiapan dan Rekrutmen Peserta
Persiapan yang dilakukan untuk Pelaksanaan pengabdian kepada masyarakat
adalah sebagai berikut:
a) Melakukan koordinasi dengan Kecamatantarget pekerjaan pengabdian pada
masyarakat.
b) Mengidentifikasi kebutuhan bimbingan teknis yang sangat menKelurahan
Andowiak dan dibutuhkan oleh pemerintah Kecamatan, Kelurahan Andowia
dan lembaga pemberdayaan masyarakat lainnya.
d) Memprangiapkan logistik dan perbekalan.
M) Konts.

Berbagai kendala pengelolaan arsip dikantor Kecamatan Andowia, seperti
kurangnya pengetahuan arsiparis maupun terbatasnya sarana dan prasarana,
antara lain kurangnya perhatian khusus terhadap ruangan untuk penyimpanan
arsip, lemari arsip yang kurang memadahi didukung dengan banyaknya arsip yang
disimpan setiap bagian bidang pekerjaan dan kurangnya perawatan khusus juga
menjadi alasan kurang tepatnya pengelolaan arsip dan kurangnya keterampilan dan
komitmen dalam penataan administrasi kantor di kantor Kecamatan Andowia.
Berdasarkan uraian diatas dapat didefinisikan permasalahan sebagai berikut;
minimnya pemahaman Aparatur Sipil Negara dan masyarakat, tentang penataan
Administrasi kantor dalam hal ini perencanaan kantor, pengorganisasi pelayananan
kantor, pelaksanaan kantor dan pengawasan kantor, minimnya keterampilan
Aparatur Sipil Negara dalam pelaksanaan tertib Administrasi, Belum terwujudnya
komitmen dan kepedulian Aparatur Sipil Negara untuk menjalankan tugas
Metode Pelaksanaan
1. Persiapan dan Rekrutmen Peserta
Persiapan yang dilakukan untuk Pelaksanaan pengabdian kepada masyarakat
adalah sebagai berikut:
a) Melakukan koordinasi dengan Kecamatantarget pekerjaan pengabdian pada
masyarakat.
b) Mengidentifikasi kebutuhan bimbingan teknis yang sangat menKelurahan
Andowiak dan dibutuhkan oleh pemerintah Kecamatan, Kelurahan Andowia
dan lembaga pemberdayaan masyarakat lainnya.
d) Memprangiapkan logistik dan perbekalan.
M) Konts.

Berbagai kendala pengelolaan arsip dikantor Kecamatan Andowia, seperti
kurangnya pengetahuan arsiparis maupun terbatasnya sarana dan prasarana,
antara lain kurangnya perhatian khusus terhadap ruangan untuk penyimpanan
arsip, lemari arsip yang kurang memadahi didukung dengan banyaknya arsip yang
disimpan setiap bagian bidang pekerjaan dan kurangnya perawatan khusus juga
menjadi alasan kurang tepatnya pengelolaan arsip dan kurangnya keterampilan dan
komitmen dalam penataan administrasi kantor di kantor Kecamatan Andowia.
Berdasarkan uraian diatas dapat didefinisikan permasalahan sebagai berikut;
minimnya pemahaman Aparatur Sipil Negara dan masyarakat, tentang penataan
Administrasi kantor dalam hal ini perencanaan kantor, pengorganisasi pelayananan
kantor, pelaksanaan kantor dan pengawasan kantor, minimnya keterampilan
Aparatur Sipil Negara dalam pelaksanaan tertib Administrasi, Belum terwujudnya
komitmen dan kepedulian Aparatur Sipil Negara untuk menjalankan tugas
Metode Pelaksanaan
1. Persiapan dan Rekrutmen Peserta
Persiapan yang dilakukan untuk Pelaksanaan pengabdian kepada masyarakat
adalah sebagai berikut:
a) Melakukan koordinasi dengan Kecamatantarget pekerjaan pengabdian pada
masyarakat.
b) Mengidentifikasi kebutuhan bimbingan teknis yang sangat menKelurahan
Andowiak dan dibutuhkan oleh pemerintah Kecamatan, Kelurahan Andowia
c) Mengidentifikasi peserta bimbingan teknis.
d) Memprsiapkan logistik dan perbekalan.
M) KoOanna.

Berbagai kendala pengelolaan arsip dikantor Kecamatan Andowia, seperti
kurangnya pengetahuan arsiparis maupun terbatasnya sarana dan prasarana,
antara lain kurangnya perhatian khusus terhadap ruangan untuk penyimpanan
arsip, lemari arsip yang kurang memadahi didukung dengan banyaknya arsip yang
disimpan setiap bagian bidang pekerjaan dan kurangnya perawatan khusus juga
menjadi alasan kurang tepatnya pengelolaan arsip dan kurangnya keterampilan dan
komitmen dalam penataan administrasi kantor di kantor Kecamatan Andowia.
Berdasarkan uraian diatas dapat didefinisikan permasalahan sebagai berikut;
minimnya pemahaman Aparatur Sipil Negara dan masyarakat, tentang penataan
Administrasi kantor dalam hal ini perencanaan kantor, pengorganisasi pelayananan
kantor, pelaksanaan kantor dan pengawasan kantor, minimnya keterampilan
Aparatur Sipil Negara dalam pelaksanaan tertib Administrasi, Belum terwujudnya
komitmen dan kepedulian Aparatur Sipil Negara untuk menjalankan tugas
Metode Pelaksanaan
1. Persiapan dan Rekrutmen Peserta
Persiapan yang dilakukan untuk Pelaksanaan pengabdian kepada masyarakat
adalah sebagai berikut:
a) Melakukan koordinasi dengan Kecamatantarget pekerjaan pengabdian pada
masyarakat.
b) Mengidentifikasi kebutuhan bimbingan teknis yang sangat menKelurahan
Andowiak dan dibutuhkan oleh pemerintah Kecamatan, Kelurahan Andowia
c) Mengidentifikasi peserta bimbingan teknis.
d) Memprsiapkan logistik dan perbekalan.
M) KoOanna.

Berbagai kendala pengelolaan arsip dikantor Kecamatan Andowia, seperti
kurangnya pengetahuan arsiparis maupun terbatasnya sarana dan prasarana,
antara lain kurangnya perhatian khusus terhadap ruangan untuk penyimpanan
arsip, lemari arsip yang kurang memadahi didukung dengan banyaknya arsip yang
disimpan setiap bagian bidang pekerjaan dan kurangnya perawatan khusus juga
menjadi alasan kurang tepatnya pengelolaan arsip dan kurangnya keterampilan dan
komitmen dalam penataan administrasi kantor di kantor Kecamatan Andowia.
Berdasarkan uraian diatas dapat didefinisikan permasalahan sebagai berikut;
minimnya pemahaman Aparatur Sipil Negara dan masyarakat, tentang penataan
Administrasi kantor dalam hal ini perencanaan kantor, pengorganisasi pelayananan
kantor, pelaksanaan kantor dan pengawasan kantor, minimnya keterampilan
Aparatur Sipil Negara dalam pelaksanaan tertib Administrasi, Belum terwujudnya
komitmen dan kepedulian Aparatur Sipil Negara untuk menjalankan tugas
Metode Pelaksanaan
1. Persiapan dan Rekrutmen Peserta
Persiapan yang dilakukan untuk Pelaksanaan pengabdian kepada masyarakat
adalah sebagai berikut:
a) Melakukan koordinasi dengan Kecamatantarget pekerjaan pengabdian pada
masyarakat.
b) Mengidentifikasi kebutuhan bimbingan teknis yang sangat menKelurahan
Andowiak dan dibutuhkan oleh pemerintah Kecamatan, Kelurahan Andowia
dan lembaga pemberdayaan masyarakat lainnya.
d) Memprangiapkan logistik dan perbekalan.
M) Konts.

Berbagai kendala pengelolaan arsip dikantor Kecamatan Andowia, seperti
kurangnya pengetahuan arsiparis maupun terbatasnya sarana dan prasarana,
antara lain kurangnya perhatian khusus terhadap ruangan untuk penyimpanan
arsip, lemari arsip yang kurang memadahi didukung dengan banyaknya arsip yang
disimpan setiap bagian bidang pekerjaan dan kurangnya perawatan khusus juga
menjadi alasan kurang tepatnya pengelolaan arsip dan kurangnya keterampilan dan
komitmen dalam penataan administrasi kantor di kantor Kecamatan Andowia.
Berdasarkan uraian diatas dapat didefinisikan permasalahan sebagai berikut;
minimnya pemahaman Aparatur Sipil Negara dan masyarakat, tentang penataan
Administrasi kantor dalam hal ini perencanaan kantor, pengorganisasi pelayananan
kantor, pelaksanaan kantor dan pengawasan kantor, minimnya keterampilan
Aparatur Sipil Negara dalam pelaksanaan tertib Administrasi, Belum terwujudnya
komitmen dan kepedulian Aparatur Sipil Negara untuk menjalankan tugas
Metode Pelaksanaan
1. Persiapan dan Rekrutmen Peserta
Persiapan yang dilakukan untuk Pelaksanaan pengabdian kepada masyarakat
adalah sebagai berikut:
a) Melakukan koordinasi dengan Kecamatantarget pekerjaan pengabdian pada
masyarakat.
b) Mengidentifikasi kebutuhan bimbingan teknis yang sangat menKelurahan
Andowiak dan dibutuhkan oleh pemerintah Kecamatan, Kelurahan Andowia
dan lembaga pemberdayaan masyarakat lainnya.
d) Memprangiapkan logistik dan perbekalan.
M) Konts.

Berbagai kendala pengelolaan arsip dikantor Kecamatan Andowia, seperti
kurangnya pengetahuan arsiparis maupun terbatasnya sarana dan prasarana,
antara lain kurangnya perhatian khusus terhadap ruangan untuk penyimpanan
arsip, lemari arsip yang kurang memadahi didukung dengan banyaknya arsip yang
disimpan setiap bagian bidang pekerjaan dan kurangnya perawatan khusus juga
menjadi alasan kurang tepatnya pengelolaan arsip dan kurangnya keterampilan dan
komitmen dalam penataan administrasi kantor di kantor Kecamatan Andowia.
Berdasarkan uraian diatas dapat didefinisikan permasalahan sebagai berikut;
minimnya pemahaman Aparatur Sipil Negara dan masyarakat, tentang penataan
Administrasi kantor dalam hal ini perencanaan kantor, pengorganisasi pelayananan
kantor, pelaksanaan kantor dan pengawasan kantor, minimnya keterampilan
Aparatur Sipil Negara dalam pelaksanaan tertib Administrasi, Belum terwujudnya
komitmen dan kepedulian Aparatur Sipil Negara untuk menjalankan tugas
Metode Pelaksanaan
1. Persiapan dan Rekrutmen Peserta
Persiapan yang dilakukan untuk Pelaksanaan pengabdian kepada masyarakat
adalah sebagai berikut:
a) Melakukan koordinasi dengan Kecamatantarget pekerjaan pengabdian pada
masyarakat.
b) Mengidentifikasi kebutuhan bimbingan teknis yang sangat menKelurahan
Andowiak dan dibutuhkan oleh pemerintah Kecamatan, Kelurahan Andowia
dan lembaga pemberdayaan masyarakat lainnya.
d) Memprangiapkan logistik dan perbekalan.

Berbagai kendala pengelolaan arsip dikantor Kecamatan Andowia, seperti
kurangnya pengetahuan arsiparis maupun terbatasnya sarana dan prasarana,
antara lain kurangnya perhatian khusus terhadap ruangan untuk penyimpanan
arsip, lemari arsip yang kurang memadahi didukung dengan banyaknya arsip yang
disimpan setiap bagian bidang pekerjaan dan kurangnya perawatan khusus juga
menjadi alasan kurang tepatnya pengelolaan arsip dan kurangnya keterampilan dan
komitmen dalam penataan administrasi kantor di kantor Kecamatan Andowia.
Berdasarkan uraian diatas dapat didefinisikan permasalahan sebagai berikut;
minimnya pemahaman Aparatur Sipil Negara dan masyarakat, tentang penataan
Administrasi kantor dalam hal ini perencanaan kantor, pengorganisasi pelayananan
kantor, pelaksanaan kantor dan pengawasan kantor, minimnya keterampilan
Aparatur Sipil Negara dalam pelaksanaan tertib Administrasi, Belum terwujudnya
komitmen dan kepedulian Aparatur Sipil Negara untuk menjalankan tugas
Metode Pelaksanaan
1. Persiapan dan Rekrutmen Peserta
Persiapan yang dilakukan untuk Pelaksanaan pengabdian kepada masyarakat
adalah sebagai berikut:
a) Melakukan koordinasi dengan Kecamatantarget pekerjaan pengabdian pada
masyarakat.
b) Mengidentifikasi kebutuhan bimbingan teknis yang sangat menKelurahan
Andowiak dan dibutuhkan oleh pemerintah Kecamatan, Kelurahan Andowia
dan lembaga pemberdayaan masyarakat lainnya.
d) Memprangiapkan logistik dan perbekalan.

Berbagai kendala pengelolaan arsip dikantor Kecamatan Andowia, seperti
kurangnya pengetahuan arsiparis maupun terbatasnya sarana dan prasarana,
antara lain kurangnya perhatian khusus terhadap ruangan untuk penyimpanan
arsip, lemari arsip yang kurang memadahi didukung dengan banyaknya arsip yang
disimpan setiap bagian bidang pekerjaan dan kurangnya perawatan khusus juga
menjadi alasan kurang tepatnya pengelolaan arsip dan kurangnya keterampilan dan
komitmen dalam penataan administrasi kantor di kantor Kecamatan Andowia.
Berdasarkan uraian diatas dapat didefinisikan permasalahan sebagai berikut;
minimnya pemahaman Aparatur Sipil Negara dan masyarakat, tentang penataan
Administrasi kantor dalam hal ini perencanaan kantor, pengorganisasi pelayananan
kantor, pelaksanaan kantor dan pengawasan kantor, minimnya keterampilan
Aparatur Sipil Negara dalam pelaksanaan tertib Administrasi, Belum terwujudnya
komitmen dan kepedulian Aparatur Sipil Negara untuk menjalankan tugas
Metode Pelaksanaan
1. Persiapan dan Rekrutmen Peserta
Persiapan yang dilakukan untuk Pelaksanaan pengabdian kepada masyarakat
adalah sebagai berikut:
a) Melakukan koordinasi dengan Kecamatantarget pekerjaan pengabdian pada
masyarakat.
b) Mengidentifikasi kebutuhan bimbingan teknis yang sangat menKelurahan
Andowiak dan dibutuhkan oleh pemerintah Kecamatan, Kelurahan Andowia
dan lembaga pemberdayaan masyarakat lainnya.
d) Memprangiapkan logistik dan perbekalan.

\section{B. Metode Pelaksanaan}

\section{Persiapan dan Rekrutmen Peserta}

Berbagai kendala pengelolaan arsip dikantor Kecamatan Andowia, seperti
rangnya pengetahuan arsiparis maupun terbatasnya sarana dan prasarana,
tara lain kurangnya perhatian khusus terhadap ruangan untuk penyimpanan
sip, lemari arsip yang kurang memadahi didukung dengan banyaknya arsip yang
impan setiap bagian bidang pekerjaan dan kurangnya perawatan khusus juga
njadi alasan kurang tepatnya pengelolaan arsip dan kurangnya keterampilan dan
mitmen dalam penataan administrasi kantor di kantor Kecamatan Andowia.
rdasarkan uraian diatas dapat didefinisikan permasalahan sebagai berikut;
nimnya pemahaman Aparatur Sipil Negara dan masyarakat, tentang penataan
ministrasi kantor dalam hal ini perencanaan kantor, pengorganisasi pelayananan
tor, pelaksanaan kantor dan pengawasan kantor, minimnya keterampilan
aratur Sipil Negara dalam pelaksanaan tertib Administrasi, Belum terwujudnya
mitmen dan kepedulian Aparatur Sipil Negara untuk menjalankan tugas
etode Pelaksanaan
Persiapan dan Rekrutmen Peserta
Persiapan yang dilakukan untuk Pelaksanaan pengabdian kepada masyarakat
adalah sebagai berikut:
a) Melakukan koordinasi dengan Kecamatantarget pekerjaan pengabdian pada
masyarakat.
b) Mengidentifikasi kebutuhan bimbingan teknis yang sangat menKelurahan
Andowiak dan dibutuhkan oleh pemerintah Kecamatan, Kelurahan Andowia
dan lembaga pemberdayaan masyarakat lainnya.
c) Mengidentifikasi peserta bimbingan teknis.
d) Memprsiapkan logistik dan perbekalan. adalah sebagai berikut :

Berbagai kendala pengelolaan arsip dikantor Kecamatan Andowia, seperti
rangnya pengetahuan arsiparis maupun terbatasnya sarana dan prasarana,
tara lain kurangnya perhatian khusus terhadap ruangan untuk penyimpanan
sip, lemari arsip yang kurang memadahi didukung dengan banyaknya arsip yang
impan setiap bagian bidang pekerjaan dan kurangnya perawatan khusus juga
njadi alasan kurang tepatnya pengelolaan arsip dan kurangnya keterampilan dan
mitmen dalam penataan administrasi kantor di kantor Kecamatan Andowia.
rdasarkan uraian diatas dapat didefinisikan permasalahan sebagai berikut;
nimnya pemahaman Aparatur Sipil Negara dan masyarakat, tentang penataan
ministrasi kantor dalam hal ini perencanaan kantor, pengorganisasi pelayananan
tor, pelaksanaan kantor dan pengawasan kantor, minimnya keterampilan
aratur Sipil Negara dalam pelaksanaan tertib Administrasi, Belum terwujudnya
mitmen dan kepedulian Aparatur Sipil Negara untuk menjalankan tugas
etode Pelaksanaan
Persiapan dan Rekrutmen Peserta
Persiapan yang dilakukan untuk Pelaksanaan pengabdian kepada masyarakat
adalah sebagai berikut:
a) Melakukan koordinasi dengan Kecamatantarget pekerjaan pengabdian pada
masyarakat.
b) Mengidentifikasi kebutuhan bimbingan teknis yang sangat menKelurahan
Andowiak dan dibutuhkan oleh pemerintah Kecamatan, Kelurahan Andowia
dan lembaga pemberdayaan masyarakat lainnya.
c) Mengidentifikasi peserta bimbingan teknis.
d) Memprsiapkan logistik dan perbekalan. masyarakat.

Berbagai kendala pengelolaan arsip dikantor Kecamatan Andowia, seperti
rangnya pengetahuan arsiparis maupun terbatasnya sarana dan prasarana,
tara lain kurangnya perhatian khusus terhadap ruangan untuk penyimpanan
sip, lemari arsip yang kurang memadahi didukung dengan banyaknya arsip yang
impan setiap bagian bidang pekerjaan dan kurangnya perawatan khusus juga
njadi alasan kurang tepatnya pengelolaan arsip dan kurangnya keterampilan dan
mitmen dalam penataan administrasi kantor di kantor Kecamatan Andowia.
rdasarkan uraian diatas dapat didefinisikan permasalahan sebagai berikut;
nimnya pemahaman Aparatur Sipil Negara dan masyarakat, tentang penataan
ministrasi kantor dalam hal ini perencanaan kantor, pengorganisasi pelayananan
tor, pelaksanaan kantor dan pengawasan kantor, minimnya keterampilan
aratur Sipil Negara dalam pelaksanaan tertib Administrasi, Belum terwujudnya
mitmen dan kepedulian Aparatur Sipil Negara untuk menjalankan tugas
etode Pelaksanaan
Persiapan dan Rekrutmen Peserta
Persiapan yang dilakukan untuk Pelaksanaan pengabdian kepada masyarakat
adalah sebagai berikut:
a) Melakukan koordinasi dengan Kecamatantarget pekerjaan pengabdian pada
masyarakat.
b) Mengidentifikasi kebutuhan bimbingan teknis yang sangat menKelurahan
Andowiak dan dibutuhkan oleh pemerintah Kecamatan, Kelurahan Andowia
dan lembaga pemberdayaan masyarakat lainnya.
c) Mengidentifikasi peserta bimbingan teknis.
d) Memprsiapkan logistik dan perbekalan.

gnagai kendala pengelolaan arsip dikantor Kecamatan Andowia, seperti
lain kurangnya perhatian khusus terhadap ruangan untuk penyimpanan
lemari arsip yang kurang memadahi didukung dengan banyaknya arsip yang
an setiap bagian bidang pekerjaan dan kurangnya perawatan khusus juga
di alasan kurang tepatnya pengelolaan arsip dan kurangnya keterampilan dan
men dalam penataan administrasi kantor di kantor Kecamatan Andowia.
sarkan uraian diatas dapat didefinisikan permasalahan sebagai berikut;
nya pemahaman Aparatur Sipil Negara dan masyarakat, tentang penataan
istrasi kantor dalam hal ini perencanaan kantor, pengorganisasi pelayananan
pelaksanaan kantor dan pengawasan kantor, minimnya keterampilan
men dan kepedulian Aparatur Sipil Negara untuk menjalankan tugas
de Pelaksanaan
rsiapan yang dilakukan untuk Pelaksanaan pengabdian kepada masyarakat
alah sebagai berikut:
Melakukan koordinasi dengan Kecamatantarget pekerjaan pengabdian pada
masyarakat.
Mengidentifikasi kebutuhan bimbingan teknis yang sangat menKelurahan
Andowiak dan dibutuhkan oleh pemerintah Kecamatan, Kelurahan Andowia
dan lembaga pemberdayaan masyarakat lainnya.
Mengidentifikasi peserta bimbingan teknis.
Memprsiapkan logistik dan perbekalan.

gnagai kendala pengelolaan arsip dikantor Kecamatan Andowia, seperti
lain kurangnya perhatian khusus terhadap ruangan untuk penyimpanan
lemari arsip yang kurang memadahi didukung dengan banyaknya arsip yang
an setiap bagian bidang pekerjaan dan kurangnya perawatan khusus juga
di alasan kurang tepatnya pengelolaan arsip dan kurangnya keterampilan dan
men dalam penataan administrasi kantor di kantor Kecamatan Andowia.
sarkan uraian diatas dapat didefinisikan permasalahan sebagai berikut;
nya pemahaman Aparatur Sipil Negara dan masyarakat, tentang penataan
istrasi kantor dalam hal ini perencanaan kantor, pengorganisasi pelayananan
pelaksanaan kantor dan pengawasan kantor, minimnya keterampilan
men dan kepedulian Aparatur Sipil Negara untuk menjalankan tugas
de Pelaksanaan
rsiapan yang dilakukan untuk Pelaksanaan pengabdian kepada masyarakat
alah sebagai berikut:
Melakukan koordinasi dengan Kecamatantarget pekerjaan pengabdian pada
masyarakat.
Mengidentifikasi kebutuhan bimbingan teknis yang sangat menKelurahan
Andowiak dan dibutuhkan oleh pemerintah Kecamatan, Kelurahan Andowia
dan lembaga pemberdayaan masyarakat lainnya.
Mengidentifikasi peserta bimbingan teknis.
Memprsiapkan logistik dan perbekalan.

Berbagai kendala pengelolaan arsip dikantor Kecamatan Andowia, seperti
angnya pengetahuan arsiparis maupun terbatasnya sarana dan prasarana,
ara lain kurangnya perhatian khusus terhadap ruangan untuk penyimpanan
ip, lemari arsip yang kurang memadahi didukung dengan banyaknya arsip yang
impan setiap bagian bidang pekerjaan dan kurangnya perawatan khusus juga
njadi alasan kurang tepatnya pengelolaan arsip dan kurangnya keterampilan dan
mitmen dalam penataan administrasi kantor di kantor Kecamatan Andowia.
rasarkan uraian diatas dapat didefinisikan permasalahan sebagai berikut;
nimnya pemahaman Aparatur Sipil Negara dan masyarakat, tentang penataan
ministrasi kantor dalam hal ini perencanaan kantor, pengorganisasi pelayananan
tor, pelaksanaan kantor dan pengawasan kantor, minimnya keterampilan
aratur Sipil Negara dalam pelaksanaan tertib Administrasi, Belum terwujudnya
mitmen dan kepedulian Aparatur Sipil Negara untuk menjalankan tugas
etode Pelaksanaan
Persiapan dan Rekrutmen Peserta
Persiapan yang dilakukan untuk Pelaksanaan pengabdian kepada masyarakat
adalah sebagai berikut:
a) Melakukan koordinasi dengan Kecamatantarget pekerjaan pengabdian pada
masyarakat.
b) Mengidentifikasi kebutuhan bimbingan teknis yang sangat menKelurahan
Andowiak dan dibutuhkan oleh pemerintah Kecamatan, Kelurahan Andowia
dan lembaga pemberdayaan masyarakat lainnya.
c) Mengidentifikasi peserta bimbingan teknis.
d) Memprsiapkan logistik dan perbekalan.

d) Memprsiapkan logistik dan perbekalan.

e) Koordinasi izin lokasi Pelaksanaan pengabdian dosen.

f) Penyusunan bahan dan materi bimbingan teknis berupa modul untuk menunjang pelaksanaan Pelaksanaan bimtek.

\section{Pelaksanaan}

Pelaksanaan Pelaksanaan pengabdian pada masyarakat dilaksanakan selama 1 (satu) bulan yang dimulai pada akhir bulan juli 2019 kami dengan akhir bulan Agustus 2019 bertempat di Aula Balai Kecamatan Andowia Kabupaten Konawe Utara Kerangka materi bimbingan Teknis dimaksud disajikan pada tabel 3.1 berikut ini:

\begin{tabular}{|c|cc|c|c|}
\hline No & \multicolumn{2}{|c|}{ Materi } & Nara Sumber & Alokasi Waktu \\
\hline $\mathbf{( 1 )}$ & \multicolumn{2}{|c|}{$(\mathbf{2})$} & $\mathbf{( 3 )}$ & (4) \\
\hline 1. & $\begin{array}{l}\text { Manajemen } \\
\text { Perkantoran }\end{array}$ & dan $\quad$ Administrasi & Sartono, S.Sos, M.Si & 3 JPL \\
\hline
\end{tabular}


Vol. 1, No. 2, Hal. 57-71, Mei 2020

\begin{tabular}{|c|l|l|c|}
\hline 2. & $\begin{array}{l}\text { Pentingnya perencanaan kantor, } \\
\text { perorganisasi pelayananan kantor, } \\
\text { pelaksanaan kantor, dan pengawasan } \\
\text { kantor guna menunjang tertib } \\
\text { administrasi }\end{array}$ & $\begin{array}{l}\text { Dr. Muh. Zein } \\
\text { Abdullah, } \\
\text { S.Sos,M.Si } \\
\text { Dr.Muh.Yusuf,S.So } \\
\text { S, M.Si }\end{array}$ & 4 JPL \\
\hline 3. & $\begin{array}{l}\text { Teori dan aplikasi surat menyurat, } \\
\text { kearsipan, dan ketatausahaan kantor, } \\
\text { perorganisasi pelayananan Model } \\
\text { Perencanaan Pembangunan Kelurahan } \\
\text { Andowia sesuai dengan kondisi Lokal } \\
\text { Kelurahan Andowia }\end{array}$ & $\begin{array}{l}\text { Dr.Adrian Tawai, } \\
\text { S.Sos, M.Si } \\
\text { Dr. Muh. Yusuf, } \\
\text { S.Sos, M.Si }\end{array}$ & 6 JPL \\
\hline 4. & $\begin{array}{l}\text { Kesepakatan Rencana Kerja Tindak } \\
\text { Lanjut (RKTL) }\end{array}$ & $\begin{array}{l}\text { Sartono, S.Sos, M.Si } \\
\text { La Ode Aslim SE, M.Si }\end{array}$ & \\
\hline & 2otal & & 2 JPL \\
\hline
\end{tabular}

\section{Hasil Dan Pembahasan}

\section{Gambaran Umum Kelurahan Andowia}

Andowia adalah sebuah Kecamatan di Konawe Utara Provinsi Sulawesi Tenggara Kecamatan ini berjarak 5 Kilo meter dari ibu kota Kabupaten Konawe Utara ke arah Selatan Andowia merupakan hasil pemakaran Kecamatan Asera Pusat Pemerintahan nya berada di Kelurahan Andowia deengan luas wilayah $595,90 \mathrm{Km}^{2}$, Kepadatan Penduduk berjumlah 10 jiwa $/ \mathrm{Km}^{2}$, Kelurahan Andowia/Kelurahan Andowia berjumlah 15 terdiri dari Ambake, Amolame, Andowia, Anggolohipo, Banggarema, Labungga, Lahimbua, Lambudoni, Lamondowo,Larobende, Laronanga, Mata Iwoi , Puusuli, Puuwunua, Dan Waworate.

Batas-batas Wilayah Kelurahan Andowia, Kecamatan Andowia, Kabupaten Konawe Utara.

- Sebelah Barat Berbatasan Dengan Kecamatan Asera dan Kabupaten Konawe.

- Sebelah Utara Berbatasan Dengan Kecamatan Asera dan Kecamatan Oheo.

- Sebelah Timur Berbatasan Dengan Kecamatan Molawe.

- Sebelah Selatan Berbatasan Dengan Kecamatan Molawe dan Kabupaten Konawe.

2. Program Kerja Utama KKN Tematik

Pelaksanaan Prorgam Kerja KKN Tematik di Kelurahan Andowia adalah Bimbingan Teknis penataan administrasi pemerintah Kelurahan Andowia. Sebagai pertimbangan mendasar di laksanakan Pelaksanaan ini adalah masih lemah penyusunan dokumen khususnnya administrasi kependudukan dan pelayanan publik di Kelurahan Andowia. Selain itu partisipasi masyarakat sangat rendah. Dengan rendahnya partisipasi masyarakat ikut serta terlibat dalam perencanaan karena kurang nya sosialisasi kepada masyarakat serta minimnya pengetahuan masyarakat terhadap perencanaan kami pada pengawasan. Dimana dokumen Administrasi di antaranya Pertama Teknis Pelaksanaan Administrasi Kelurahan Andowia, terdiri dari pencatatn data dan jenis-jenis administrasi Kelurahan Andowia. Kedua tertib administrasi Kelurahan Andowia terdiri dari sekolompok orang, kerja sama, pembagian kerja, Pelaksanaan 
administrasi, tujuan yang di inginkan. Ketiga kedudukan administrasi Kelurahan Andowia dalam menunjang efektivitas kerja pemerintah Kelurahan Andowia di antaranya pembinaan disiplin dalam pelaksanaan administrasi terhadap kepala seksi pemerintahan, ketentraman dan ketertiban umum, seksi pemberdayaan masyarakat dan pembangunan, seksi kesejahteraan masyarakat, serta seksi pelayanan umum.

\section{Kedudukan Pemerintah Kelurahan Andowia Dalam Penataan Administrasi}

Seperti yang telah diuraikan sebelumnya, bahwa tugas dan fungsi pemerintah Kelurahan Andowia begitu luas dan kompleks, yakni meliputi seluruh aspek kehidupan masyarakat. Hal ini berarti tugas aparat Kelurahan Andowia juga demikian adanya, karena apparat Kelurahan Andowia merupakan salah satu unsur pemerintahan Kelurahan Andowia, oleh karena itu untuk kepentingan kajian ini dibatasi pada pelaksanaan tugas apparat Kelurahan Andowia dalam arti sempit (ketatausahaan) yang meliputi: surat-menyurat dan penyimpanannya (kearsipan).

\section{Teknis Pelaksanaan Administrasi Kelurahan Andowia}

\section{a. Pencatatan Data}

Peranan Pencatatan Data dilakukan untuk:

1. Pengelolaan administrasi pada semua tingkatan organisasi pelayanan termasuk organisasi pelayanan Pemerintahan Kelurahan Andowia merupakan suatu tuntutan yang sangat diperlukan, karena dengan terbentuknya administasi yang baik di bidang pemerintahan, pembangunan maupun kemasyarakatan dengan kata lain bahwa suatu Pelaksanaan pemerintahan pada tingkat Kelurahan Andowia akan berhasil dengan baik apabila didukung oleh suatu sistem adminitrasi yang tertib dan teratur.

2. Sistem pengelolaan administrasi Pemerintahan Kelurahan Andowia diarahkan kepada suatu pencatatan data melalui Dokumen-dokumen Administrasi Kelurahan Andowia sesuai dengan peraturan perundang-undangan yang berlaku yang dicatat secara tertib dan teratur berdasarkan PelaksanaanPelaksanaan setiap harinya sehingga diharapkan akan selalu tersedia data yang diperlukan dalam berbagai hal.

3. Dengan semakin meningkatnya penataan pemerintahan dan pelaksanaan pembangunan dari tahun ke tahun, maka keadaan demikian itu menuntut pula pengembangan sistem administrasi terutama di tingkat Kelurahan Andowia khususnya dalam upaya mewujudkan Kelurahan Andowia yang mampu berfungsi sebagai sumber data dan informasi bagi semua Pelaksanaan pemerintahan dan pelaksanaan pembangunan secara nasional.

4. Penataan pemerintahan Kelurahan Andowia yang merupakan subsistem dari sistem penataan pemerintahan menjadikan Kelurahan Andowia sebagai tumpuan dan ujung tombak dalam penataan pemerintahan dan pelaksanaan pembangunan sekaligus sumber data dan informasi dalam penentuan berbagai kebijaksanaan pemerintahan secara nasional. Dalam posisi seperti 
ini salah satu faktor yang menentukan keberhasilan penataan pemerintahan Kelurahan Andowia adalah terwujudnya penataan sistem administrasi pemerintahan Kelurahan Andowia yang berdaya guna dan berhasil guna. Dengan semakin meningkatnya penataan administrasi pemerintahan pada tingkat Kelurahan Andowia semakin penting artinya dalam upaya mewujudkan otonomi Kelurahan Andowia yang kuat sebagaimana diharapkan oleh UU No. 32 tahun 2004 dan sekaligus mendukung otonomi daerah.

5. Ketertiban dalam penataan administrasi pada tingkat Kelurahan Andowia merupakan salah satu bukti keberhasilan penataan pemerintahan dan pelaksanaan pembangunan secara keseluruhan. Telah menjadi kenyataan bahwa Kelurahan Andowia dalam kedudukannya sebagai sumber data dan informasi bagi segala Pelaksanaan pemerintahan dan pembangunan mempunyai peranan yang sangat menentukan karena keberhasilan terhadap pelaksanaan berbagai program pemerintahan dan pembangunan pada semua tingkatan sangat tergantung kepada penyusunan perencanaan yang berpangkal pada data dan informasi yang akurat.

6. Pelaksanaan pencatatan data pada Dokumen Administrasi Pemerintahan Kelurahan Andowia dikelompokkan menjadi 6 jenis Dokumen.

\section{b. Jenis-Jenis Administrasi}

\section{1) Jenis Administrasi Kelurahan Andowia}

a. Administrasi Umum;

b. Administrasi Penduduk;

c. Administrasi Keuangan;

d. Administrasi Pembangunan;

e. Administrasi Badan Permusyawaratan Kelurahan Andowia;

f. Administrasi Lainnya;

Sesuai dengan uraian diatas Pemerintah Kelurahan AndowiaAndowia harus memperhatikan teknis dalam pelaksanaan administrasi, karna hal ini sangat penting dalam penyelenggaran pemerintahan. Sesuai dengan wawancara peneliti dengan Lurah Andowia dikatakan bahwa

"Penataan administrasikantor yang ada di Kelurahan AndowiaAndowia, sudah tertata dengan baik dan model-model draf yang tersimpan di lemari dengan menggukan bundel-bundel dokumennya pun sudah lengkap. Tapi dalam pelaksanaanya masih ada beberapa data yang belum terpenuhi didalam dokumen administrasi, salah satunya dokumen kepemilikan tanah yang seharusnya lebih penting dalam penataan pemerintahan tapi dalam hal ini data dan informasi yang ada dalam kantor perlu pembenahan sistem informasi sehingga dalam pelayanan kepada masyarakat bisa berjalan dengan apa yang di harapkan oleh masyarakat khususnya di Kelurahan Andowia ini." 
Berdasarkan pernyataan yang di ungkapkan oleh lurah dapat di tarik kesimpulan bahwa menguraikan perProbleman yang ada dalam pelaksanaan administrasi umum jenis dokumen kepemilikan tanah masyarakat Andowia.

\section{2) Tertib Administrasi Kelurahan Andowia Dalam Bentuk Administrasi Umum Jenis Dokumen Kepemilikan Tanah}

Pengolahan administrasi yang ada di Kelurahan AndowiaAndowia masih banyak yang belum lengkap sesuai dengan dokumen-dokumen administrasi yang sudah ada. Tapi, peneliti memperhatikan ada dokumen administrasi yang termasuk penting dalam penataan pemerintahan, isi dokumennya masih kosong yaitu dokumen kepemilikan tanah.

Hasil wawancara peneliti dengan Pemerintah Kelurahan Andowia yang di dalamnya aparatKelurahan Andowia, tentang administrasi umum yaitu dokumen kepemilikan tanah, peneliti menemukan beberapa faktor yang menghambat jalanya proses administrasi kepemilikan tanah Kelurahan Andowia.

Berdasarkan Konsep dari Silalahi ada beberapa hal yang di sebut sebagai administrasi

\section{a) Sekelomok Orang}

Dalam hal ini pemerintah Kelurahan Andowia harus membentuk struktur pemerintahan yang ada diKelurahan AndowiaAndowia, untuk membantu pemerintah Kelurahan Andowia dalam pelaksanaan penataan pemerintahan sesuai dengan tujuan yang ingin dicapai. Hukum tua yang mempunyai otoritas dalam pembentukan struktur pemerintahan sudah melaksanakan tugasnya dengan baik dan telah memilih orang-orang yang mempunyai kemampuan kepemimpinan yang baik. Dalam pelaksanaan administrasi yang ada diKelurahan Andowia sangat diperlukan kerja sama dari beberapa orang sehingga dapat tercapai administrasi Kelurahan Andowia yang diinginkan.

\section{b) Kerja Sama}

Hasil penelitian yang kami lihat dilapangan, kerja sama antara aparat pemerintahan tidak terlihat berjalan dengan begitu baik ini di karenakan ada beberapa aparatKelurahan Andowia yang belum memahami tugas dan fungsi mereka sebagai aparatKelurahan Andowia dan ada juga aparat Kelurahan Andowia yang tidak mendukung jalanya penataan pemerintahan. Ini terbukti dengan adanya aparatKelurahan Andowia yang kami saat ini sudah tidak mau menjalankan tugasnya sebagai aparat Kelurahan Andowia, sehingga masyarakat Kelurahan Andowia tidak mengetahui lagi status dari aparat tersebut apakah dia masih masuk dalam struktur organisasi pelayanan pemerintahan atau sudah tidak termasuk. Lurah pun menanggapi tentang hal ini,

"Kami selaku pemerintah Kelurahan Andowia sudah mengetahui hal yang terjadi dilingkup aparatKelurahan Andowia, bahwa ada aparatKelurahan Andowia yang sudah tidak mau menjalankan tugasnya sebagai aparat. Problem ini terjadi dikarenakan aparatKelurahan Andowia tersebut memiliki perselisihan dengan teman aparat yang lain, karna dilihat oleh 
apparat Kelurahan Andowia tersebut bahwa aparatKelurahan Andowia yang lain masih lalai dalam menjalankan tugasnya. saya sebagai Lurah sudah mengambil tindakan untuk membicarakan Problem ini dengan aparat tersebut, tapi kami saat ini tidak dihiraukan. Ini menjadi pelajaran yang sangat penting bagi saya untuk lebih memperhatikan Tanggung Jawabyang dijalankan oleh apparat Kelurahan Andowia, serta menjaga kekeluargaan pemerintah Kelurahan Andowia. Di awal tahun 2019 pemerintah Kelurahan Andowia akan mengisi kekosongan yang ada dalam struktur aparatKelurahan Andowia.

Berdasarkan pernyataan yang di ungkapkan oleh lurah karenakan pemerintah Kelurahan Andowia belum menindaklanjuti atau belum melakukan pergantian buat aparatKelurahan Andowia tersebut, sehinggah ini yang membuat lemahnya kerja sama antara aparat pemerintah Kelurahan Andowia.

\section{c) Pembagian Kerja}

Pembagian kerja adalah Pelaksanaan administrasi bukan sekedar Pelaksanaan kerja sama, melainkan kerja sama tersebut harus didasarkan pada pembagian kerja yang jelas. Pelaksanaan administrasi Kelurahan Andowia dilaksanakan oleh sekertaris Kelurahan Andowia dan dibantu oleh aparatKelurahan Andowia yang lain, atau biasa disebut Kaur-kaur yang ada diKelurahan Andowia.Dalam penataan administrasi di Kelurahan AndowiaAndowia, sekertaris Kelurahan Andowia sudah melakukan tugasnya dangan begitu baik, tapi yang terlihat dilapangan administrasi yang ada di Kelurahan AndowiaAndowia masih lemah. Ini di karenakan aparatKelurahan Andowia yang lain tidak membantu sekertaris Kelurahan Andowia dalam pelaksanaan administrasi. Dalam pelaksanaan administrasi Kelurahan Andowia peran dari Kaur-kaur ini sangatlah penting untuk mencapai administrasi Kelurahan Andowia yang tersusun dengan baik. Dari sinilah pemerintah Kelurahan Andowia harus cakap dalam memilih Kaur Pemerintah, karna dituntut harus mempunyai kemampuan dan potensi yang baik dalam penataan pemerintahan. Sekertaris Kelurahan Andowia mengatakan bahwa peran dari Kaur pemerintah masih kurang dalam membantu pelaksanaan administrasi Kelurahan Andowia

"Kamisaat ini memang administrasi yang ada diKelurahan Andowia masih belum lengkap dokumen yang telah di siapkan, ini di karenakan aparatKelurahan Andowia yang lain belum cukup maksimal dalam membantu saya dalam pembuatan administrasi secara teknis maupun secara konseptual Kelurahan Andowia"

\section{d) Pelaksanaan yang runtut dalam suatu proses}

Adalah Pelaksanaan administrasi berlangsung dalam tahapan-tahapan tertentu secara berkesinambungan. Tanggung jawab dalamPelaksanaan administrasi yang ada diKelurahan AndowiaAndowia sudah berjalan sebagaimana mestinya tetapi dalam pelaksanannya masih ada beberapa hal yang harus diperhatikan supaya proses Pelaksanaan administrasi tersebut bisa berjalan dengan begitu baik dan tepat target pekerjaan. Seperti yang terjadi saat ini, Pelaksanaan 
administrasi yang seharusnya dilakukan dikantor Kelurahan Andowia hanya digunakan dirumah pribadi sekretaris Kelurahan Andowia dan hal ini memperlambat berjalannya proses administrasi karena yang terjadi bahwa aparatKelurahan Andowia tidak leluasa dalam membantu sekretaris Kelurahan Andowia dalam menyusun administrasi Kelurahan Andowia, Ditambah lagi dengan tugas sekretaris Kelurahan Andowia yang lebih banyak dilaksanakan dikantor kecamatan amurang barat sehingga tahapan-tahapan administrasi tidak sesuai dan tidak pada pembagian kerjanya. Ini juga yang membuat administrasi kepemilikan tanah yang ada diKelurahan AndowiaAndowia menjadi terhamabat dari tahun ke tahun, sebenarnya hal ini sangat penting dalam penataan pemerintahan, dan ini juga yang akan menjaga kerukunan yang ada didalam lingkungan masyarakat Kelurahan Andowia.

Penataan Administrasi yang masih lemah dalam menanggulangi administrasi kepemilikan tanah Penataan pemerintahan yang ada di Kelurahan AndowiaAndowia sudah berlangsung selama 1 tahun di periode Bpk Parman S.Sos. Hasil wawancara peneliti, peneliti menemukan bahwa pemerintah yang ada di kecamatan Andowia, sepanjang priode ini tidak mengontrol akan hal yang terjadi di Kelurahan AndowiaAndowia dalam pelaksanaan administrasi, sehingga tidak ada peran yang penting dari pemerintah kecamatan mengenai hal ini.

\section{3) Penataan Administrasi Kelurahan Andowia Dalam Guna Menunjang PelaksanaanTertib Administrasi Pemerintahan Kelurahan Andowia}

\section{a) Pembinaan Disiplin Pegawai/AparatKelurahan Andowia}

Upaya pemberdayaan dapat dilakukan untuk meningkatkan efisiensi dan efektifitas kerja aparat pemerintah desa dalam melaksanakan tugas pokoknya dan fungsi organisasi pelayanan adalah melalui pembinaan disiplin, hal ini dimaksudkan supaya para Aparatdalam melaksanakan tugas sehari-harinya senantiasa patuh dan taat pada berbagai ketentuan yang berlaku dan menunjukan prestasi kerja yang tinggi.Usaha untuk meningkatkan kualitas kerja melalui pembinaan disiplin, diperlukan suatu pedoman atau kerangka yang memuat dengan jelas sistem metode dan prosedur pembinaan serta tujuan dan target pekerjaan setiap bentuk Aparatyang bermental baik berdaya guna, berhasil guna dan sadar akan tanggung jawab dalam melaksanakan dan menjalankan Tanggung Jawabpemerintahan dan pembangunan. Adapun bentuk penerapan disiplin Aparatpada Kantor Kelurahan AndowiaAndowia adalah pembinaan disiplin waktu kerja, sebab dengan ketepatan pada jam masuk kantor sangat erat kaitannya dengan disiplin lainnya. Menurut pengamatan penulis penerapan disiplin waktu jam kerja pada dasarnya belum dilaksanakan dengan baik. Pelanggaran disiplin waktu bagi AparatKelurahan AndowiaAndowia cenderung sering terjadi.

Hasil wawancara dengan Sekretaris Kelurahan AndowiaAndowia mengatakan bahwa rendahnya kehadiran Aparatdikarenakan kurangnya kesadaran Aparatuntuk mentaati aturan yang berlaku di kantor. Oleh karena pembinaan disiplin Aparatdimaksudkan untuk meningkatkan kesadaran efisiensi dan efektifitas kerja Aparatguna mencapai pelaksanaan tugas kantor dan 
peningkatan pelayanan kepada masyarakat. Peran Kepala Kelurahan Andowia yang paling menonjol dalam Pelaksanaan administrasi Kelurahan Andowia adalah pemberdayaan aparat Kelurahan Andowia di arahkan untuk meningkatkan prestasi kerja dalam rangka mewujudkan sumber daya manusia yang profesional dalam bidang kerjanya. Pemberdayaan aparat sangat diperlukan untuk mengantisipasi perkembangan dalam dunia kependudukan yang demikian cepat sehingga membutuhkan aparat yang profesional dalam menjalankan tugasnya dengan baik. Guna meningkatkan kemampuan dalam mengantisipasi Tanggung Jawabdi bidang pemerintahan dan pembangunan yang semakin kompleks maka dalam menjalankan tugas pokok dan fungsi Kantor Kelurahan Andowia telah melaksanakan pemberdayaan terhadap aparatnya sebagai berikut:

\section{Pendidikan dan Pelatihan}

Pendidikan dan pelatihan merupakan upaya untuk memberdayakan aparat, terutama untuk meningkatkan kemampuan intelektual dankepribadian. Pendidikan yang dilakukan dalam suatu proses pengembangan kemampuan bertujuan ke arah yang diinginkan oleh organisasi pelayanan yang bersangkutan. Sedangkan pelatihan adalah bagian dari proses pendidikan yang bertujuan untuk meningkatkan kemampuan atau keterampilan khusus seseorang. Pendidikan dan pelatihan yang diikuti oleh aparat Kelurahan AndowiaAndowia diharapkan nantinya mampu mengerjakan tugas-tugasnya dengan baik yang dibebankan kepadanya tanpa arahan langsung dari pihak atasannya.Pendidikan dan pelatihan dapat dipandang sebagai salah satu jalur untuk meningkatkan kemampuan aparat Kelurahan Andowia dalam melayani kepentingan masyarakat.Pentingnva program pendidikan dan pelatihan bertujuan untuk mengetahui pentingnya materi yang di berikan yang berdasarkan pengalaman dan keterampilan dalam bekerja.

Meningkatkan kemampuan mereka dalam mengelola PelaksanaanPelaksanaan sesuai dengan profesinya, Untuk meningkatkan pengetahuan mereka.

2. Pemberian Motivasi Kerja

Bentuk motivasi kerja yang di berikan oleh Kelurahan Andowia adalah memberikan dorongan dan menyerahkan sepenuhnya Tanggung Jawabkepada bawahannya untuk dilaksanakan dengan penuh rasa tanggung jawab dalam pelaksanaan mengerjakan tugas pokok dan fungsi serta menyelesaikan tugas dan tanggung jawab berkenaan dengan pelayanan kepada masyakat.

Berikut ini dapat di tampilkan gambar kegiatan workshoop penataan administrasi kantor guna menunjang tertib administrasi kantor di kelurahan andowia kecamatan andowia kecamatan konawe utara yang di sampaikan narasumber Sartono, S.Sos., M.Si ,Menjelaskan secara rinci penataan administrasi pemerintah dan pelaksanaan tertib administrasi kelurahan 
secara teoritis dan aplikasinya dalam penataan administrasi dan tertib administrasi kelurahan.

Penataan administrasi pemerintah kelurahanPelaksanaan administrasi berlangsung dalam tahapan-tahapan tertentu secara berkesinambungan. Tanggung jawab dalamPelaksanaan administrasi yang ada diKelurahan Andowia sudah berjalan sebagaimana mestinya tetapi dalam pelaksanannya masih ada beberapa hal yang harus diperhatikan supaya proses Pelaksanaan administrasi tersebut bisa berjalan dengan begitu baik dan tepat target pekerjaan. Seperti yang terjadi saat ini, Pelaksanaan administrasi yang seharusnya dilakukan dikantor Kelurahan Andowia hanya digunakan dirumah pribadi sekretaris Kelurahan Andowia dan hal ini memperlambat berjalannya proses administrasi karena yang terjadi bahwa aparatKelurahan Andowia tidak leluasa dalam membantu.

\section{Kegiatan Penunjang}

Adapun kegiatan penunjang KKN tematik Terintegrasi PPM Dosen adalah sebagai berikut

a) Kegiatan pengimputan data dan pengelolaan pencatatan data kependudukan

Pengelolaan administrasi pada semua tingkatan tingkatan kelurahan dalam pelayanan publik termasuk organisasi kemasyarakatan Kelurahan Andowia dan Kelurahan Andowia merupakan suatu tuntutan yang sangat diperlukan, karena dengan terbentuknya administasi yang baik di bidang pemerintahan, pembangunan maupun kemasyarakatan dengan kata lain bahwa suatu Pelaksanaan pemerintahan pada tingkat Kelurahan Andowia akan berhasil dengan baik apabila didukung oleh suatu sistem adminitrasi kependudukan yang tertib dan teratur. Berikut di sajikan gambar mahasiswa KKN Tematik Yang Memfasilitasi pengimputan dan pencatatan data dalam website kelurahan.

b) Kegiatan pembuatan tapal batas di lingkugan RT/RW

Kegiatan Pembuatan Tapal batas di tiap lingkungan RT/RW di kelurahan Andowia Kecamatan Andowia yang di lakukan oleh koordinator kelurahan dan rekan - rekan pesetrta KKN Tematik Terintegrasi mengerjakan dan menyiapkan bahan material membuat desain tapal batas dengan menggunakan papan, cat, gergaji,paku, kuas, dan lain-lain. Yang di komadoi oleh Satria Selaku Koordinator kelurahan sehingga terlihat lingkungan kelurahan Andowia memiliki batas-batas lingkungan yang teratur. Yang di kerjakan kegiatan tersebut di laksanakan memakan waktu 2 hari kegiatan terlaksana dengan baik.

Penataan lingkungan kelurahan Andowia dalam hal ini penataan lingkungan kelurahan di arahkan pada pembuatan tapal batas dan pemberian papan nama ruangan pemerintah kelurahan hal di laksanakan dalam kondisi sangat kumu sehingga memberikan kesan tidak memberikan nilai estetika dalam penataan ruang kelurahan dan ruang kerja kantor kelurahan.

Selain itu keindahan lingkungan dapat memberikan suasan harmonis, indah, dan kesejukan bagi parah warga setempat dimana dengan lingkungan kerja yang nyaman, asri dan indah dapat memberikan suasana dan kondisi 
lingkungan kantor lurah dan lingkungan pemukinan warga yang menjadi iklim terlihat lebih nyaman dan tentram.

\section{c) Bakti Sosial}

Bakti sosial yang di selenggarakan oleh peserta mahasiswa KKN tematik terdiri dari beberapa kegiatan antara lain kegiatan mencat pagar rumah warga, pagar kantor kelurahan dan kegiatan mencat rumah warga kelurahan Andowia. Bakti sosial yang di selenggarakan sebagai rasa peduli dan sebagai wahana untuk meningkatkan hubungan sosial masyarakat, serta memperkuat tali silaturahmi bagi sesama umat manusia sebagai wujud kepekaan sosial bagi peserta mahasiswa KKN tematik Terintegrasi.

d) Keterlibatan dalam kepenatian perayaan hari kemerdekaan RI ke $\mathbf{7 4}$

Kegiatan kepanitian hari kemerdekaan RI Ke 74 peserta mahasiswa KKN Tematik Terintegrasi terlibat dalam memberikan arahan kepada tingkat sekolah dasar kepada murid-murid SD menyelenggarakan kegiatan lomba yang di selenggarakan oleh pramuka millenial sekonut yaitu lomba yel-yel, barisberbaris, baca puisi , hafalan surat-surat pendek dan adzan.

Peserta KKN memberikan arahan kepada murid-murid SD dalam lomba yang di selenggarakan oleh pramuka millenial sekonut yang di komandoi oleh Alham selaku panitia lomba dengan demikian pula moment mahasiswa peserta KKN menggunakan sebagai wadah untuk belajar, berlatih, mengembangkan diri mahasiswa terlibat mulai dari kegiatan rapat sampai dengan acara penyelenggaraan kegiatan serta sampai pada pelaksanaan upacara bendera

\section{Kesimpulan Dan Saran \\ 1. Kesimpulan} lain:

Berdasarkan uraian Pelaksanaan di atas dapat di simpulkan beberapa hal, antara

1. Pemerintah yang ada di Kelurahan Andowia Kecamatan Andowia Kabupaten Konawe Utara belum mampu mengatur atau menata administrasi Kelurahan Andowia dengan baik, sebab pemerintah Kelurahan Andowia belum memahami butul pentingnya administrasi Kelurahan Andowia dalam penataan pemerintahan. Sehingga proses pelaksanaan administrasi menjadi lambat dan tidak sesuai dengan tujuan yang ingin dicapai.

2. Pemerintah Kelurahan Andowia belum efektif dalam proses pelaksanaan administrasi Kelurahan Andowia, karna masih banyak Pelaksanaan administrasi yang belum dapat diselesaikan, seperti jenis administrasi umum dokumen kepemilikan tanah Kelurahan Andowia Kecamatan Andowia yang kami amati saat ini tidak ada catatan apa pun dalam dokumen tersebut. Ini yang menyebabkan keberhasilan Pemerintah Kelurahan Andowia dinilai masih kurang baik dalam penataan Pemerintahan.

\section{Saran}


1. Pemerintah yang ada di Kelurahan Andowia sebaiknya kembali menata dengan baik proses pelaksanaan administrasi, melengkapi data-data yang masih kurang dan lebih bertanggung jawab lagi dalam tugasnya. Tempat pelaksanaan administrasi juga bagus dilakukan dikantor Kelurahan Andowia, supaya aparat yang lain lebih bebas dalam membantu sekertaris Kelurahan Andowia dalam Pelaksanaan administrasi.

2. Pemerintah Kelurahan Andowia sebaiknya lebih memperhatikan hal-hal apa saja yang penting dalam proses penataan pemerintahan, supaya ke depan-nya tidak akan terjadi Problem dalam lingkungan masyarakat dan pemerintah mampu melindungi proses penataan pemerintahan. Terlebih khusus pemerintah harus memperhatikan administrasi kepemilikan tanah yang ada di Kelurahan Andowia karna data-datanya masih kosong dalam dokumen administrasi tersebut supaya hal ini akan berdampak baik dalam mengukur keberhasilan Pemerintah Kelurahan Andowia.

\section{DAFTAR PUSTAKA}

Abubakar, Hadi, (1997). Cara-cara pengelolaan kearsipan yang praktis dan efisien, jakarta: Djambatan. 1996). Pola kearsipan moderen sistem kartu kendali. Jakarta : Djambatan

Amsyah, Zukifli. (2001), Manajemen kearsipan. Jakarta : Gramedia pustaka Utama.

Amsyah, Zukifli. (2001). Manajemen sistem informasi. Jakarta : Gramedia Pustaka Utama.

Anwar. Syamsul, (1999). Kearsipan. Bandung: Titian IImu

Anhar. (1980). Menyusun surat dan kearsipan. Jakarta: Depdikbud.

Basuki. Sulistyo. (2003). Manajemen Arsip Dinamis. Jakarta : Gramedia.

Barthos. Bashir. (2000). Manajemen kearsipan. Jakarta : Bumi Aksara.

Daryan. Yayan. (1998). Terminologi Kearsipan. Jakarta : PT Signa Cipta Utama.

Gie. The Liang. (2000). Administrasi Perkantoran Moderen. Yogyakarta. Liberty.

Haryadi hezl. (2000). Administrasi perkantoran untuk manajemen. Bandung, sinar baru

Kadir. Abdul. (2003). Pengenalan Sistem Informasi. Yogyakarta. Andi.

Karso. (1999). Kearsipan. Purwokerto. LPAP Prefesional.

Komaruddin. (2001). Azas-Azas Manajemen Perksantoran: Suatu Pendekatan Sistem Informasi Manajemen. Bandung: Kappa Sigma.

-----(1993). Manajemen Kantor Teori Dan Praktek. Bandung: Trigenda Karya.

Kotler. Philips, (1991). Manajemen Pemasaran. Jakarta Prenhallindo. 
Laudon. C. Kenneth, (2008). Management Information System: Managing The Digital Firm. Pearson prentice Hill.

Lukman Sampara. (1999). Manajemen Kualitas Pelayanan. Jakarta: STIA LAN PRES

Mills, Gooffrey, (1991). Manajemen Moderen. Jakarta: Binarupa Aksara.

Madiana. Gina. (1999). Sistem Kearsipan Praktis. Jakarta: Pustaka Sinar Harapan.

----(1994). Penataan berkas dalam Manajemen Kearsipan. Jakarta: Pustaka SinarHarapan.

Maulana. M.N. (1994). Administrasi Kantor. Bandung: Alumni.

Moekijat. (1986). Tata Laksana Kantor. Bandung : Alumni.

Sedandayanti (2001). Sumber daya manusiadan produktif kerja. Bandung. 